\title{
International Reserves and Underdeveloped Capital Markets
}

\author{
Kathryn M. E. Dominguez, University of Michigan and NBER
}

\section{Introduction}

China's official foreign exchange reserves have passed the $\$ 2$ trillion mark, equivalent to approximately $\$ 2,000$ for every Chinese citizen. ${ }^{1}$ Although China is currently the country with the largest foreign reserve accumulation, reserves have risen dramatically for many developing countries in recent years. Economic models suggest a number of motivations for reserve accumulation, including precautionary and mercantilist motives, which may be especially compelling for developing countries. However, the recent upsurge in reserve accumulation among developing countries cannot be explained solely on the basis of these rationales. This paper examines a potential new role for reserve accumulation in helping to mitigate distortions created by the undeveloped financial markets of developing countries.

The growth and liberalization of financial markets in industrial countries over the past three decades provide developing countries unprecedented access to international capital markets and expose them to sometimes dramatic and sudden swings in capital flows. The 1990s witnessed a number of economic crises in developing countries that were accompanied by (if not precipitated by) outflows of international capital. This recent experience with capital flow reversals can, at least in part, explain the desire by developing countries to decrease their dependence on international capital by accumulating foreign reserves.

While global financial markets have recently been tumultuous, the trend has been for financial markets in industrial countries to deepen and broaden at the same time that markets in many developing countries remain incomplete. This paper focuses on the implications for developing countries of underdeveloped capital markets. In a series of papers, Ricardo Caballero and coauthors have developed models showing that 
underdeveloped capital markets cause undervaluation of international resources by the private sector, which encourages excessive external borrowing, dollarization of international liabilities, and other actions that increase their exposure to potential capital shortfalls (see, e.g., Caballero and Krishnamurthy 2001, 2004, 2005). One way to mitigate the costs of this exposure is for developing country governments to accumulate international reserves. ${ }^{2}$

The analysis in this paper considers the role of financial market underdevelopment in motivating reserve accumulation by developing countries, while also allowing for the more traditional mercantilist and precautionary motives. In theory there can be a strict distinction between the precautionary motive, which seeks to smooth consumption fluctuations, and the underdeveloped financial markets motive, which seeks to offset a tightening of a financial constraint. However, in practice, these two motivations for reserve accumulation may be difficult to disentangle. In particular, the desire to smooth intertemporal consumption is likely to be influenced by financial market constraints. Whereas Aiyagari (1994) in a closed economy framework suggests that for the U.S. private sector precautionary savings are likely to be sufficient to relax financial constraints, this is less likely to be the case in developing countries in which distortions may bias the private sector against saving, thereby providing incentives for the public sector to step in.

Official foreign exchange reserve holdings by developing countries greatly exceed those of industrial countries (in the case of China, in absolute terms, and in most other cases relative to the sizes of their economies). This is yet another example of the capital flows paradox described by Lucas (1990). Capital should flow to where its return is highest, which ought to be where capital is scare. If instead capital flows from the capitalpoor developing world to the capital-rich industrialized world, the explanation is likely to be found in distortions not entertained in standard models.

\section{Motives for the Accumulation of International Reserves}

International reserves held by government authorities are part of national wealth and were originally important for countries with fixed exchange rates that wanted to avoid costly adjustments to disturbances in the external sector of the economy. For example, if a country ran a current account deficit, reserves could be used by the government to forestall an exchange rate depreciation that might otherwise occur. However, in this view of reserves, as a country's level of wealth increases over time or if a 
country moves away from a fixed exchange rate regime, it is less clear how much of a share of the national wealth should be devoted to international reserve assets.

Heller (1966) provides one of the first attempts at calculating an optimal country-specific level of international reserves based on what he termed the precautionary motive. The three parameters he thought important to this calculation include (1) the cost of adjusting to an external imbalance (measured as the propensity to import), (2) the cost of holding liquid international reserves (measured as the difference between the return on the reserves relative to a benchmark return on domestic bonds), and (3) the probability that there will actually be a need for reserves of a given magnitude (based on the history of past external imbalances).

In the period following the 1971 breakdown of the Bretton Woods System, while many industrial countries moved away from fixed exchange rate systems toward more flexible regimes, countries continued to hold reserves despite the disappearance of their original purpose, which was to help finance current account imbalances. In practice there seem to have evolved a number of "rules of thumb" to determine optimal reserve levels loosely based on Heller's precautionary motive. These rules included maintaining reserves equivalent to (1) 3 months of imports (to offset current account shocks), (2) $5 \%-20 \%$ of M2 (to be able to shore up confidence in the value of the domestic currency in the event of a currency crisis), and (3) the value of all debt obligations falling due within the following year (in the event of a sudden disappearance of short-term capital inflows). ${ }^{3}$

All these rules of thumb imply a desire on the part of governments to acquire reserves to serve as a cushion against adverse economic shocks of one form or another and as such can be categorized as satisfying Heller's precautionary motive. Frenkel and Jovanovic (1981) provide a more formal approach to modeling the precautionary motive for holding reserves using a stochastic inventory-theoretic framework. Their model indicates that optimal reserve holdings increase with the volatility of reserves (which are presumably influenced by current account shocks, the value of the domestic currency, and capital inflows) subject to a fixed cost of reserve accumulation and the opportunity cost of holding reserves. Ben-Bassat and Gottlieb (1992) follow in this buffer stock modeling tradition while also linking international reserves with sovereign risk. ${ }^{4}$

An alternative view of reserve accumulation is that it is the by-product of a government strategy to keep the international value of the domestic currency low in order to boost export growth. In this view purchases of foreign reserves are not motivated by a desire to smooth consumption in 
the face of external shocks, but rather they are the unintended consequence of sterilized interventions in the foreign exchange market. ${ }^{5}$ This rationale for reserve accumulation, typically labeled the mercantilist motive, has been advanced by Dooley, Folkerts-Landau, and Garber (2003) as a description of the development strategy followed by many East Asian countries, particularly China.

There have been a number of recent empirical studies attempting to measure whether the precautionary or mercantilist motive better explains foreign reserve accumulations by both industrialized and developing countries. These studies generally find evidence in support of both motivations (see, e.g., Aizenman and Lee 2007), while at the same time finding that neither motivation fully explains the recent upsurge in reserve accumulations by developing countries (Jeanne 2007; Jeanne and Ranciere 2009). As figure 1 indicates, any theory of official reserve accumulation that hopes to explain the recent data will need to match the timing of the dramatic increase in reserve accumulations by developing

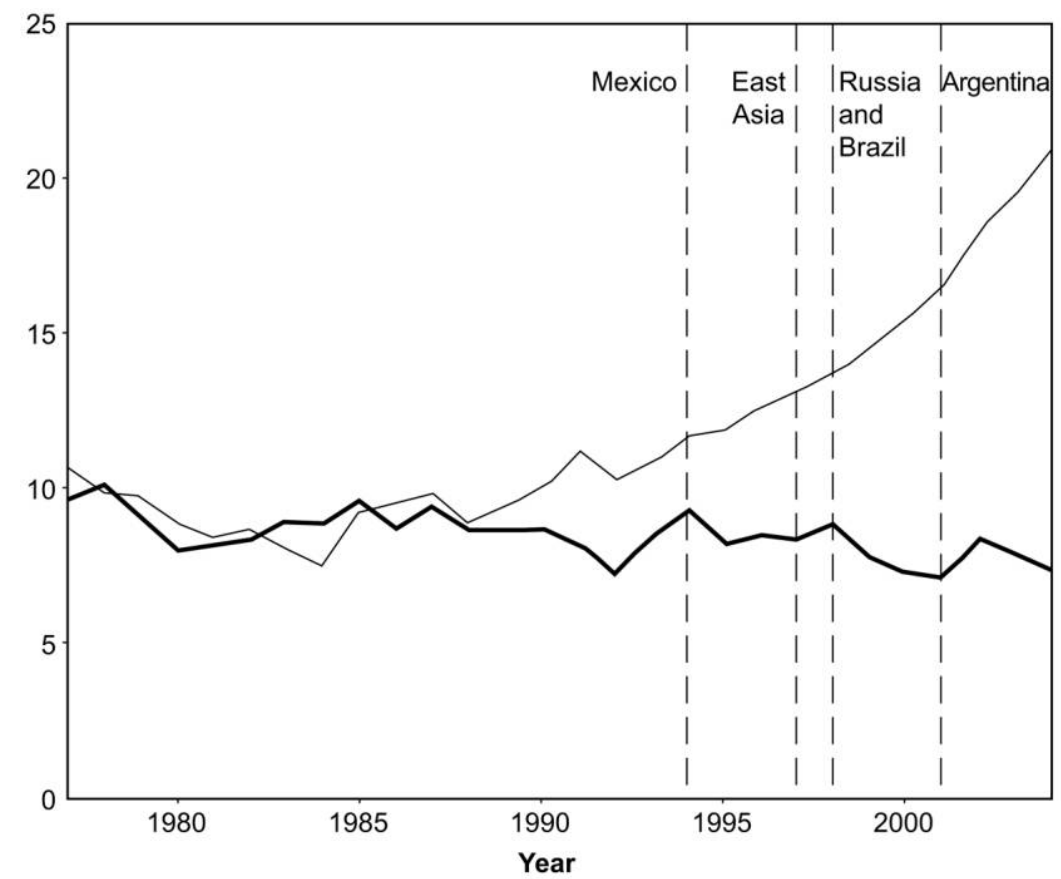

— Industrialized Countries _ Developing Countries

Fig. 1. Foreign reserves as a percentage of GDP, 1977-2004. Source: Lane and MilesiFerretti (2007), external wealth of nations database. 
countries over the 1990s and early 2000s. Even if we allow for an increase in precautionary holdings in the aftermath of the developing country crises of the 1990s, studies suggest that current reserve accumulations far exceed warranted levels (Jeanne 2007). ${ }^{6}$

Table 1 presents data from the financial accounts of industrialized and developing countries over the period 1990-2004. For developing countries, over $40 \%$ of foreign asset accumulation consists of official reserves, whereas for industrialized countries official reserves make up only $2 \%$ of gross foreign assets. Figure 2 provides a time-series view of the decomposition of foreign assets for developing countries over time. The figure highlights the increasing relative importance of official reserve accumulation for developing countries especially since 2000. On the liability side, developing countries rely much more heavily on foreign direct investment (FDI) than the industrialized countries do. ${ }^{7}$ Figure 3 depicts official reserves as a fraction of net FDI liabilities, in which the recent dramatic upsurge in reserves evident in figure 1 for developing countries (where reserves are measured as a fraction of GDP) is no longer apparent. Hence if one views reserves in the context of private-sector (FDI) liabilities, the trend patterns of reserve accumulation across industrial and developing countries are no longer so starkly divergent.

Underlying most standard models of economic growth is the assumption that investment leads to capital accumulation, which in turn leads to higher levels of production. It is therefore instructive to consider how measures of capital flows (as shown in the cross-country financial accounts reported in table 1) are related to aggregate investment rates.

Table 1

Reserve Accumulation and the Financial Account, 1990-2004

\begin{tabular}{lcc}
\hline Financial Account Category & $\begin{array}{c}\text { Industrial } \\
\text { Countries }\end{array}$ & $\begin{array}{c}\text { Developing } \\
\text { Countries }\end{array}$ \\
\hline Composition of the increase in gross foreign assets: & & \\
$\quad$ FDI & 22.90 & 14.87 \\
$\quad$ Portfolio & 19.19 & 9.99 \\
$\quad$ Other & 55.64 & 33.38 \\
$\quad$ Reserves & 2.27 & 41.76 \\
Composition of the increase in gross foreign liabilities: & & \\
$\quad$ FDI & 19.35 & 41.57 \\
$\quad$ Portfolio & 19.25 & 20.06 \\
$\quad$ Other & 61.41 & 38.37 \\
BIS decomposition of foreign liabilities: & & \\
$\quad$ Public & 22.08 & 30.49 \\
$\quad$ Private & 77.92 & 69.51 \\
\hline
\end{tabular}

Source: International Monetary Fund, Balance of Payments Statistics, and Bank for International Settlements (BIS). 


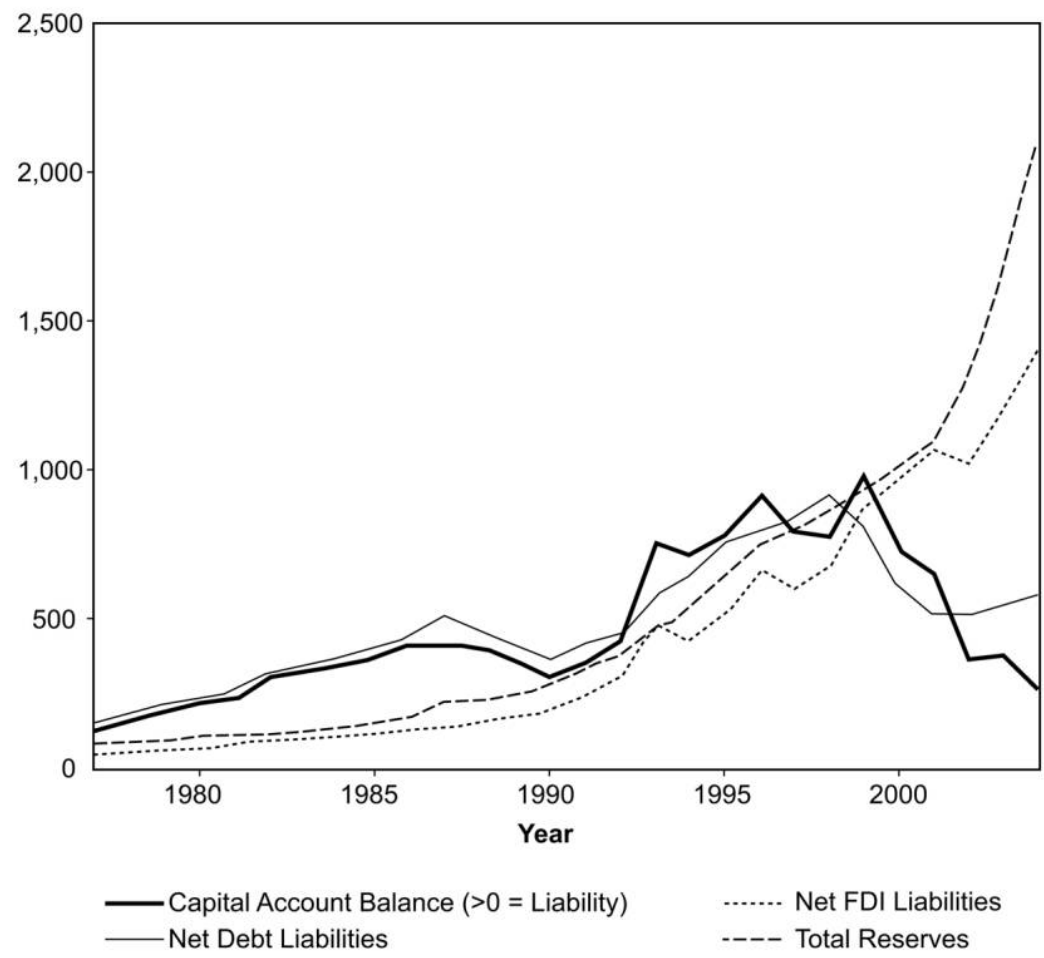

Fig. 2. Foreign reserves and net liabilities for developing countries, 1977-2004 (billions of U.S. dollars). Source: Lane and Milesi-Ferretti (2007), external wealth of nations database.

Chen (2007) shows that higher investment rates are associated with lower net capital inflows for developing countries. Further, the component of capital flows that is driving this counterintuitive result is official foreign reserves. Figure 4 presents a cross-country scatter plot of investment rates and reserve holdings showing a significant positive relationship for developing countries. A similar scatter plot for industrialized countries shows no relationship between investment and reserves.

The negative relationship between rates of investment and capital inflows for developing countries most likely reflects credit constraints. The pace of financial market development, like reserve accumulation, has diverged markedly between industrialized countries, where markets have generally deepened and broadened, and developing countries, where this deepening has yet to take place. It seems reasonable to hypothesize that in countries with underdeveloped capital markets the private sector faces constraints on its ability to borrow. In this situation the government's accumulation of reserves may act as a substitute for what would 


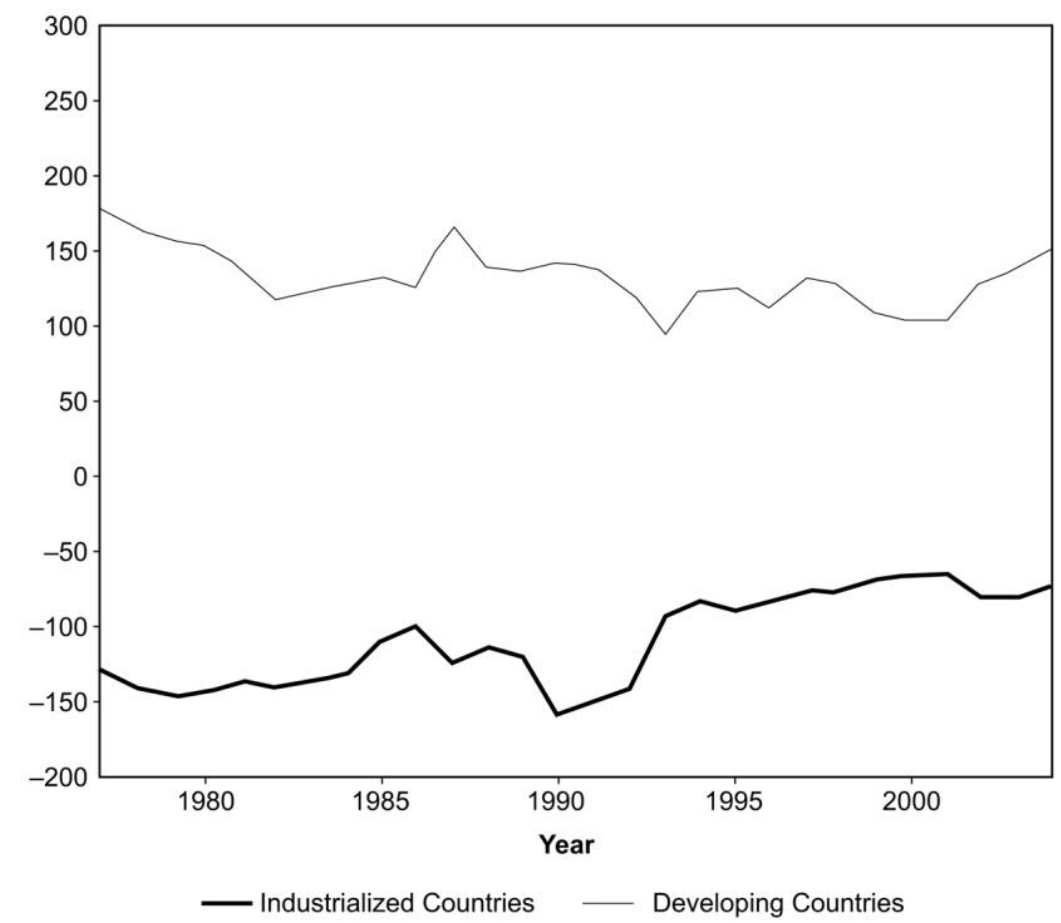

Fig. 3. Foreign reserves as a share of net FDI liabilities, 1977-2004. Source: Lane and Milesi-Ferretti (2007), external wealth of nations database.

otherwise be private-sector capital outflows. The next section presents a simple model to help clarify the role of reserve accumulation in loosening financial constraints for countries with less developed financial markets.

\section{A Simple Model of Private-Sector External Underinsurance}

It is useful to start with a simple example to highlight the problem of underinsurance by the private sector in developing countries. Consider an economy over three periods with a single consumption good. In period 0 firms make initial investments, in period 1 some firms need to reinvest as part of the normal restructuring of an economy, and in period 2 the output is produced.

In period 1 the firms that need to make additional investments will be able to produce less than otherwise, though with full reinvestment all firms produce the same output. Those firms that need to reinvest finance this by borrowing and must provide their creditors with collateral. If we make the realistic assumption that domestic lenders allow some fraction 


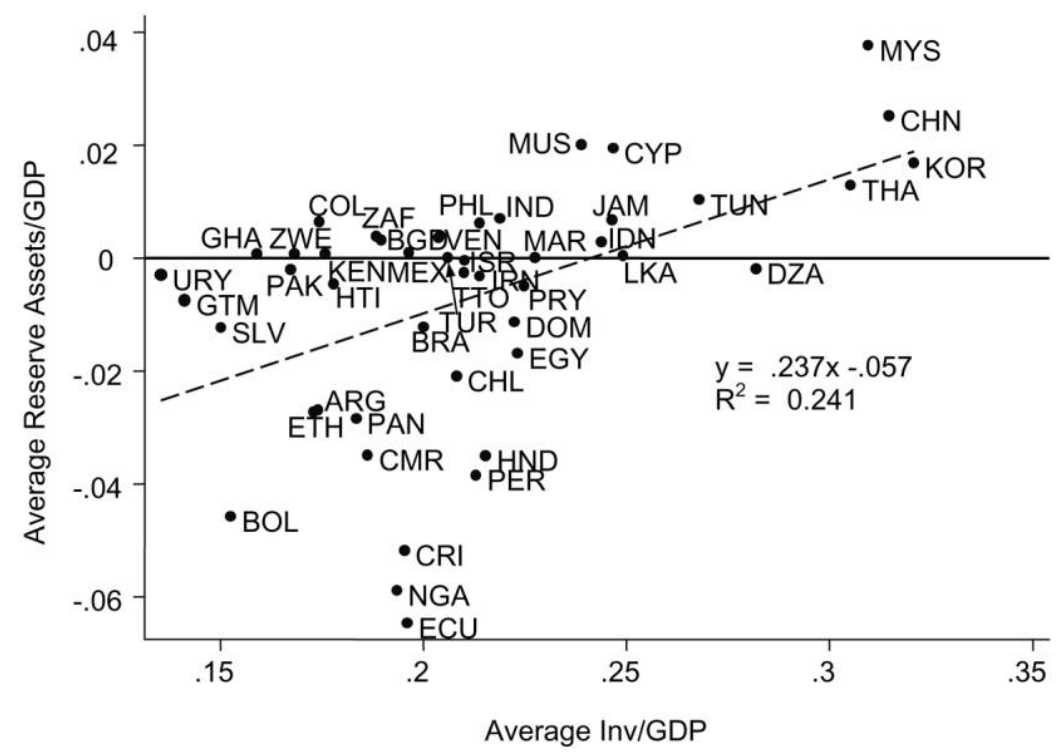

Fig. 4. Investment and foreign reserves for developing countries. Source: International Financial Statistics and World Development Indicators; investment/GDP and reserves/ GDP are averages over 1980-2001, from Chen (2007).

of domestic plant and equipment to serve as collateral, whereas foreign lenders do not, collateral is limited in an asymmetric way; firms will have less access to foreign lenders than they do to domestic lenders. In this simple setup the supply of loans can be assumed to be elastic where the domestic and foreign interest rates are equalized, up to the point that firms borrow the maximum available from foreigners and beyond this point the supply of loans is completely inelastic. ${ }^{8}$ The domestic interest rate in period 1 lies above the foreign interest rate, as a consequence of the more binding collateral constraint on foreign borrowing, and below the marginal product of full reinvestment.

If firms know that they may be financially constrained in period 1, they should optimally borrow less in period 0 in order to save resources. Yet the model suggests that firms will not insure themselves against this potential financing constraint. Why not? The problem is that the return to savings in period 0 does not reflect the true marginal product of financing in period 1 because of the distortions caused by collateral constraints. In equilibrium, external financing is undervalued, and as a consequence firms will be underinsured against potential capital shortfalls.

There are a number of possible solutions to the underinsurance problem, at least in theory. The key is to find a way to bring the ex post price 
of international resources in line with the marginal product of reinvestment. One such solution is reserve accumulation by the government. In this case, governments purchase international bonds and sterilize the effects of this purchase on the home money supply by issuing domestic bonds. If the interest rate offered on these domestic bonds in period 0 is higher than the period 1 domestic interest rate, the government is essentially subsidizing savings in period 0 , which is exactly what is needed to mitigate the underinsurance problem.

\section{Empirical Evidence Connecting Reserve Accumulation, Private-Sector Underinsurance, and Financial Market Underdevelopment}

This simple model provides two important predictions for reserveaccumulating countries. The first implication is that these countries will exhibit private-sector underinsurance against future capital shortfalls. The second implication is that there will be a wedge between the collateral value of domestic projects in the home country and international valuations of the same projects. In practice, while cross-country data on private- and public-sector external debt are available, data measuring the "collateral wedge" are not. There is, however, a large literature focused on the measurement of financial market development that is likely to be directly related to collateral constraints (see, e.g., Beck, Demirgüç-Kunt, and Levine 2000). This literature provides a number of suggested measures of financial market (under)development including financial openness (Chinn and Ito 2006), money and quasi money supply as a percentage of GDP (Lane and Burke 2001; Obstfeld et al. 2008), and the sum of private credit creation and stock market capitalization (Chinn and Ito 2009). Another measure of financial market development is the extent of external liabilities, based on the assumption that countries with less developed domestic financial markets also have fewer external liabilities. Figure 5 shows one such measure of financial development ( fin_dev1) that sums foreign portfolio equity and debt liabilities divided by GDP for industrialized and developing countries over the period 1977-2004. ${ }^{9}$ The figure shows that while this measure of financial markets has increased steadily in the industrialized countries, the growth rate of financial markets has been substantially slower for developing countries. It is also the case that the divergence in growth rates between the two groups of countries widens at around the same time as reserve accumulation by developing countries starts to accelerate. 


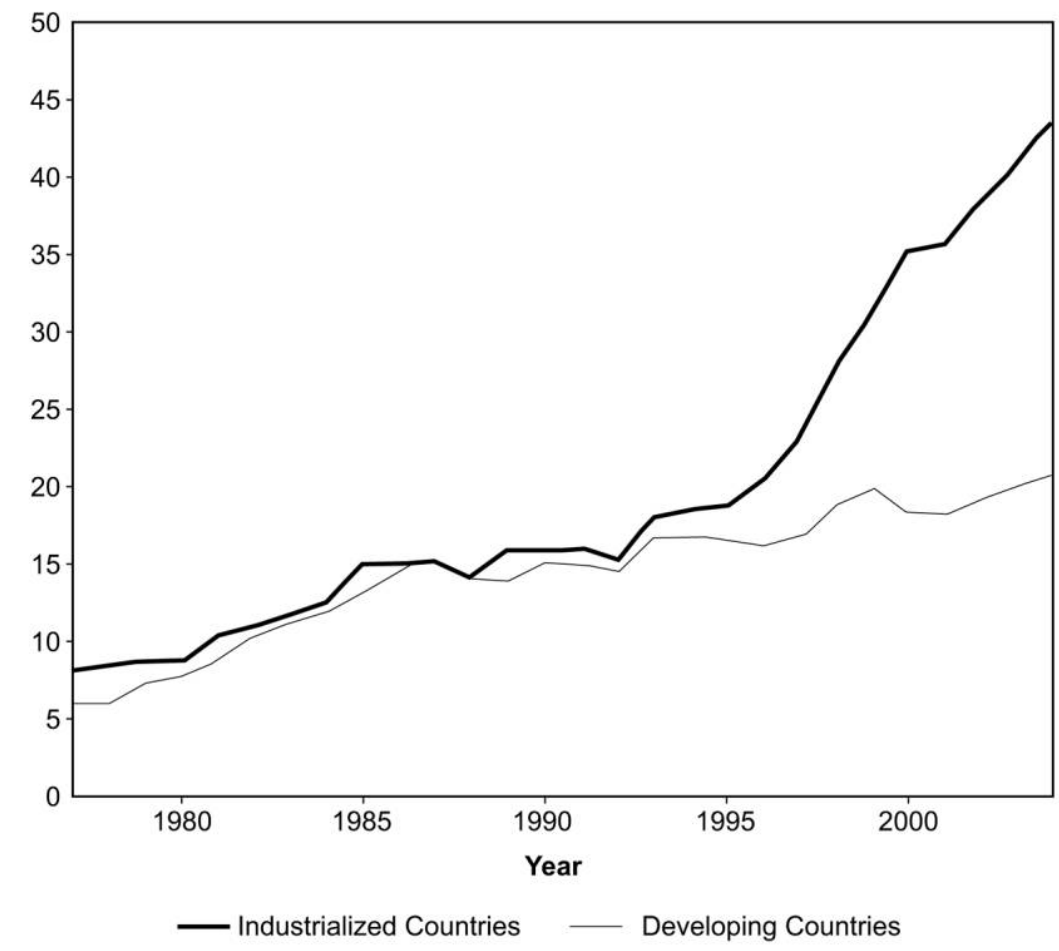

Fig. 5. Financial market development, fin_dev1, 1977-2004 (based on the size of foreign equity and debt liabilities). Source: Lane and Milesi-Ferretti (2007), external wealth of nations database; measured as the sum of foreign equity and debt liabilities over GDP; excludes Luxembourg.

An alternative measure of financial market development ( fin_dev2) focuses on the size of domestic financial markets. Figure 6, which measures financial development as the sum of a country's domestic private credit creation and stock market capitalization as a ratio of GDP, shows again the widening divergence between industrialized and developing countries in the late 1990s. Interestingly, this measure of domestic financial market size rises for industrialized countries (and to some extent developing countries) earlier than is apparent in figure 5, which is based on external rather than domestic liabilities.

Yet another measure of financial markets, focused more narrowly on the banking sector, is the ratio of money and quasi money to GDP. Obstfeld et al. (2008) make the case that the primary reason for reserve accumulation is to protect the domestic banking sector during periods of capital flight. In their view, financial development increases the need for reserves because it allows domestic residents to convert domestic bank 


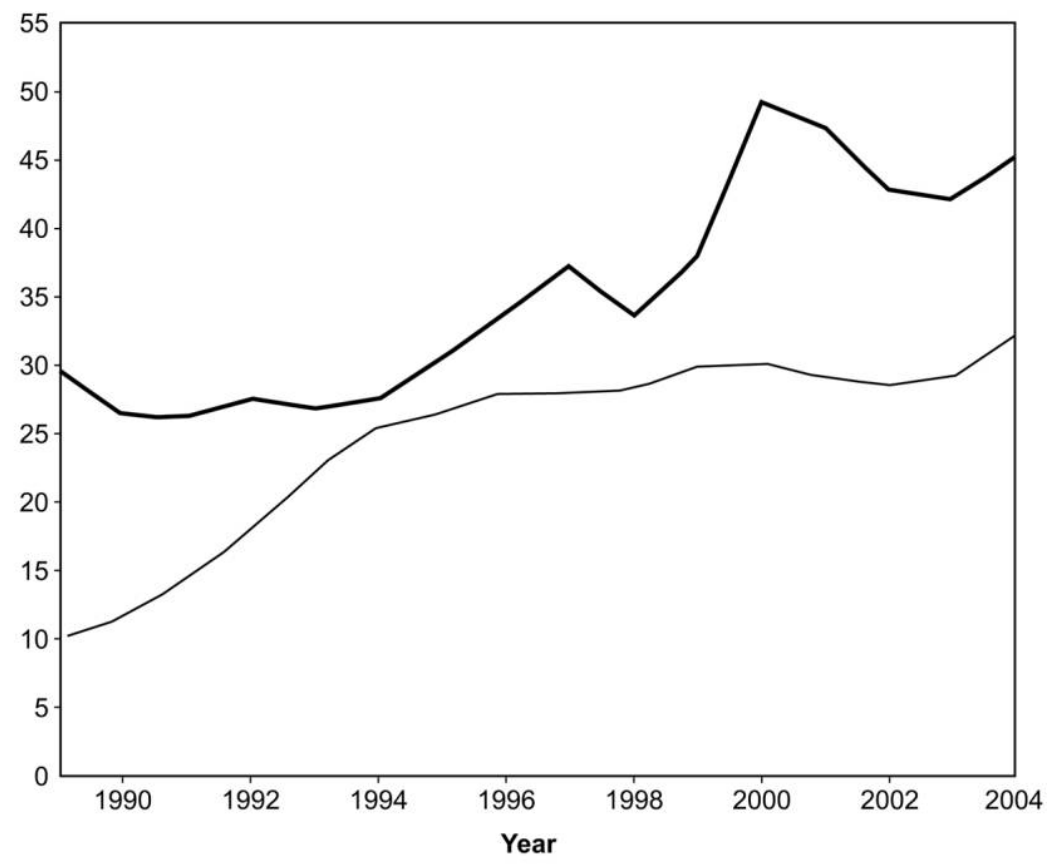

—Industrialized Countries —Developing Countries

Fig. 6. Financial market development, fin_dev2, 1988-2004 (based on domestic market size). Source: World Bank database on financial development and structure, measured as the sum of a country's private credit creation and stock market capitalization as a ratio of GDP.

deposits into foreign exchange, leading to both a run on the banking system and a depreciation of the domestic currency. Figure 7 depicts the ratio of M2 to GDP for industrialized and developing countries, which shows a steady upward trend for developing countries over this time period.

Financial market development need not be measured only in terms of the size of markets or deposits; presumably the quality of institutions within a country will also influence the depth and breadth of markets. Cheung and Ito (2009) focus on the relationship between a number of country-specific institutional variables (corruption, bureaucratic quality, law and order, form of government, government fractionalization) and reserve accumulation and find weak evidence for their importance. One potential explanation is that many of these indicators do not change, or change only infrequently in some countries. In the empirical work to follow, country fixed effects are included to capture these time-invariant institutional differences. 


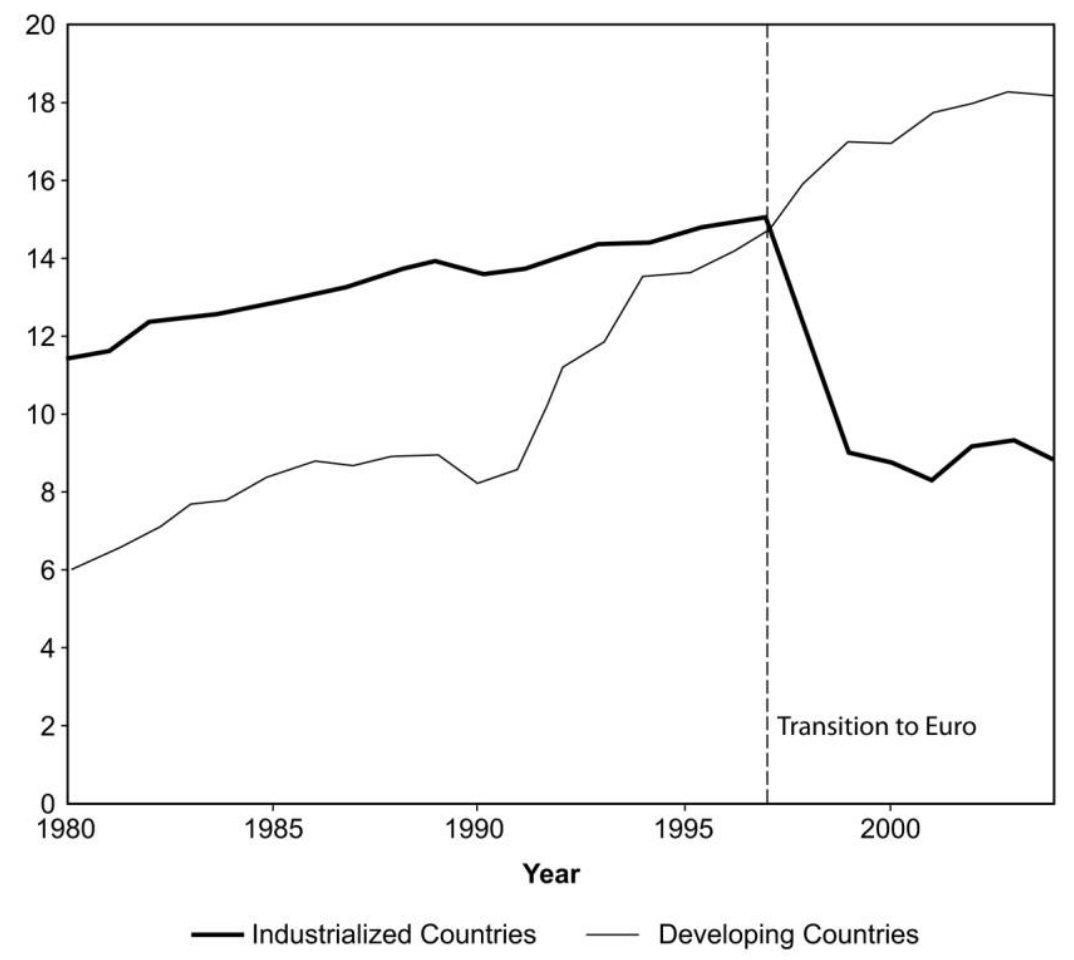

Fig. 7. Ratio of M2 money supply to GDP, 1980-2004. Source: World Development Indicators; excludes Euro Zone countries after 1999.

In the empirical literature that attempts to estimate reserve holdings for panels of countries based on mercantilist and precautionary motives, ${ }^{10}$ the standard regression specification includes scale factors (GDP), an indicator of exchange rate flexibility, indicators of openness and vulnerability to external shocks, the share of imports in GDP, and the ratio of M2 to GDP. ${ }^{11}$ Column 1 of table 2 presents the results of a panel regression that includes 56 (industrialized and developing) ${ }^{12}$ countries over the 1977-2004 time period using this standard specification:

$$
\begin{aligned}
R_{i t}= & \alpha_{0}+\alpha_{1} \mathrm{GDP}_{i t}+\alpha_{2} \text { ExRate }_{i t}+\alpha_{3} \mathrm{CC}_{i t}+\alpha_{4} \text { Crisis }_{i t}+\alpha_{5} \text { CurOver }_{i t} \\
& +\alpha_{6} \text { ShImp }_{i t}+\alpha_{7} \text { ShM2 }_{i t}+\varepsilon_{i t},
\end{aligned}
$$

where $R$ is holdings of foreign reserves valued in logged millions of U.S. dollars (from Lane and Milesi-Ferretti 2007), ExRate is an exchange rate classification based on the Reinhart and Rogoff (2004) de facto regimes, 


\section{Table 2}

Panel Regressions Explaining Reserve Holdings Based on Precautionary, Mercantilist, and Financial Market Underdevelopment Motivations (Country Fixed Effects)

\begin{tabular}{|c|c|c|c|c|}
\hline & $\begin{array}{c}\text { Standard } \\
\text { Specification: } \\
\text { Precautionary } \\
\text { and Mercantilist } \\
\text { Motives } \\
\text { (1) }\end{array}$ & $\begin{array}{l}\text { Add: Private } \\
\text { and Public } \\
\text { Liabilities } \\
\text { (2) }\end{array}$ & $\begin{array}{l}\text { Add: Measure } \\
\text { of External } \\
\text { Liabilities }^{\mathrm{a}} \\
\text { (fin_dev1) } \\
\text { (3) }\end{array}$ & $\begin{array}{l}\text { Add: Measure } \\
\text { of Domestic } \\
\text { Liabilities }^{b} \\
\text { (fin_dev2) } \\
(4)\end{array}$ \\
\hline Constant & $\begin{array}{l}-7.20^{* * *} \\
\quad(.46)\end{array}$ & $\begin{array}{c}-5.51^{* * *} \\
(.52)\end{array}$ & $\begin{array}{c}-4.84^{* * *} \\
(.52)\end{array}$ & $\begin{array}{c}-6.84^{* * *} \\
(.64)\end{array}$ \\
\hline GDP & $\begin{array}{l}1.30^{* * *} \\
(.04)\end{array}$ & $\begin{array}{l}.84^{* * *} \\
(.06)\end{array}$ & $\begin{array}{l}.73^{* * *} \\
(.06)\end{array}$ & $\begin{array}{l}.84^{* * *} \\
(.07)\end{array}$ \\
\hline Exchange rate regime & $\begin{array}{c}-.06 \\
(.49)\end{array}$ & $\begin{array}{l}.03 \\
(.04)\end{array}$ & $\begin{array}{r}-.002 \\
(.04)\end{array}$ & $\begin{array}{c}-.04 \\
(.05)\end{array}$ \\
\hline Capital controls (kaopen) & $\begin{array}{l}-.07^{* * * *} \\
(.02)\end{array}$ & $\begin{array}{l}.003 \\
(.02)\end{array}$ & $\begin{array}{c}-.008 \\
(.01)\end{array}$ & $\begin{array}{l}.004 \\
(.02)\end{array}$ \\
\hline Crisis dummy & $\begin{array}{l}-.37^{* * *} \\
(.08)\end{array}$ & $\begin{array}{l}-.27^{* * *} \\
(.07)\end{array}$ & $\begin{array}{l}-.26^{* * *} \\
(.07)\end{array}$ & $\begin{array}{l}-.28^{* * *} \\
(.07)\end{array}$ \\
\hline Currency overvaluation & $\begin{array}{l}-.007^{* * *} \\
(.001)\end{array}$ & $\begin{array}{l}-.007^{* * *} \\
(.001)\end{array}$ & $\begin{array}{l}-.007^{* * * *} \\
(.001)\end{array}$ & $\begin{array}{l}-.005^{* * * *} \\
(.001)\end{array}$ \\
\hline Share of imports & $\begin{array}{l}1.81^{* * *} \\
(.25)\end{array}$ & $\begin{array}{l}1.31^{* * *} \\
(.23)\end{array}$ & $\begin{array}{l}1.54^{* * *} \\
(.23)\end{array}$ & $\begin{array}{l}1.02^{* * *} \\
(.29)\end{array}$ \\
\hline Share of M2 & $\begin{array}{l}.49^{* * *} \\
(.13)\end{array}$ & $\begin{array}{l}.43^{* * *} \\
(.12)\end{array}$ & $\begin{array}{l}.37^{* * *} \\
(.11)\end{array}$ & $\begin{array}{l}.73^{* * *} \\
(.15)\end{array}$ \\
\hline Public liabilities & & $\begin{array}{l}-.05^{*} \\
(.03)\end{array}$ & $\begin{array}{l}-.02^{*} \\
(.01)\end{array}$ & $\begin{array}{l}-.07^{* *} \\
(.03)\end{array}$ \\
\hline Private liabilities & & $\begin{array}{l}.46^{* * *} \\
(.03)\end{array}$ & $\begin{array}{l}.50^{* * *} \\
(.03)\end{array}$ & $\begin{array}{l}.53^{* * *} \\
(.04)\end{array}$ \\
\hline $\begin{array}{c}\text { Financial market } \\
\text { development }\end{array}$ & & & $\begin{array}{l}-.38^{* * *} \\
(.06)\end{array}$ & $\begin{array}{l}-.21^{* * *} \\
(.05)\end{array}$ \\
\hline Country fixed effects & Yes & Yes & Yes & Yes \\
\hline$R^{2}$ within & .72 & .77 & .78 & .77 \\
\hline$R^{2}$ between & .78 & .81 & .82 & .83 \\
\hline Time observations & 1,017 & 1,017 & 1,017 & 712 \\
\hline Number of countries & 50 & 50 & 50 & 49 \\
\hline
\end{tabular}

Note: Robust standard errors clustered by country are in parentheses. See app. C for explanations of the variables and data sources.

aThis measure of financial market development is based on each country's foreign equity and bond liabilities (graphed in fig. 5).

${ }^{\mathrm{b}}$ This measure of financial market development is based on each country's domestic equity and bond liabilities (graphed in fig. 6); this measure is not available for China and is also unavailable for a number of countries prior to 1988 (see app. C for details).

"Significant at the $90 \%$ confidence level.

${ }^{* *}$ Significant at the $95 \%$ confidence level.

${ }^{* * *}$ Significant at the $99 \%$ confidence level. 
CC measures financial account openness (capital controls) based on Chinn and Ito's (2006) classifications, Crisis indicates the dates of currency crises as defined by Frankel and Rose (1996), CurOver indicates currency overvaluation relative to purchasing power parity (PPP), ShImp is the share of imports of goods and services in GDP, and ShM2 is the ratio of M2 to GDP. The panel estimation includes country fixed effects (so that coefficients are estimated from the time-series variation within countries).

The results from this standard regression specification suggest that the various explanatory variables enter with the expected signs. Wealthier countries hold more reserves than poorer countries. Countries that have more open capital markets (potentially making them more vulnerable to sudden stops) hold more reserves. The indicator of currency crises suggests, as expected, that those countries experiencing crises held fewer reserves during their crises. Those countries whose exchange rate is "undervalued" relative to PPP, have higher shares of imports relative to GDP, and have higher ratios of M2 to GDP hold more reserves.

Columns 2 and 3 in table 2 include additional variables suggested by the potential role of underdeveloped financial markets in explaining reserve accumulation by developing countries. One issue that arises in this context is how to distinguish proxies for the precautionary motive (the CC, Crisis, and ShM2 variables) from those that reflect financial market underdevelopment. The precautionary motive for holding reserves stems from the desire to smooth consumption distortions intertemporally in the face of sudden reversals of international capital inflows. Of course, it may well be that those countries most likely to face sudden stops (or capital flight) are also countries that have underdeveloped financial markets, ${ }^{13}$ potentially making it difficult to separate these two motives for reserve accumulation. The objective here is not to attempt to allocate weights across the different motives for reserve accumulations, but rather to expand the set of explanatory variables in the empirical specification to incorporate the insights provided by the underinsurance view, and in doing so test whether one can more readily explain the most recent upsurge in reserve accumulation.

An important feature of the simple model presented earlier is its emphasis on the role of public-sector reserve accumulation as a solution to the private-sector external underinsurance problem. One way to capture this interaction between the private and public sectors is to test whether reserves are influenced differently by private and public liabilities. The regression reported in column 2 of table 2 includes measures of public and private liabilities as explanatory variables. As the model predicts, countries with higher levels of private-sector liabilities hold greater 
reserves, whereas countries with higher levels of public-sector liabilities hold fewer reserves. ${ }^{14}$

Columns 3 and 4 of table 2 include the two alternative measures of financial market development, the first based on the size of external liabilities and the second based on the size of domestic liabilities. Recall that the model predicts that countries with less developed financial markets are likely to hold greater reserves. This prediction is confirmed in both sets of regression results, in that the sign of the financial market development indicator is negative and highly statistically significant. Three points are worth noting from these results: (1) the size and significance of the standard precautionary and mercantilist variables are little changed by the inclusion of the financial development measure; (2) both measures of financial market development (based on external and domestic liabilities) yield similar results (the measure based on the size of domestic markets is not available for China and for a number of other countries over certain years so that the sample size is substantially smaller in this specification); ${ }^{15}$ and (3) the prediction from the Obstfeld et al. (2008) model that financial development increases the need for reserves is not borne out in these regressions. While I find, as they do, that the share of M2 to GDP is economically and statistically significant in explaining reserve accumulation, increased financial development in these regressions decreases reserve accumulation. ${ }^{16}$ These results provide suggestive empirical support for the hypothesis that official reserve accumulation may, at least in part, be working to loosen the financial constraints faced by developing countries with underdeveloped financial markets.

While some of the empirical specifications presented in table 2 are fairly standard in the literature, two issues are worth noting. First, a number of the explanatory variables included in the various regression specifications are likely to be correlated. For example, wealthier countries are more likely to have open capital markets, high levels of liabilities, and highly developed financial markets. Table 3 presents cross correlations across a number of the key variables used in the regressions that were found to have relatively high correlations (variables with low cross correlations are not included in the table). The highest (positive) correlation is found between public and private external liabilities, followed by the correlations of public and private liabilities and GDP (indicating, unsurprisingly, that it is the wealthier countries that are doing most of the borrowing). The domestic financial development measure (fin_dev2) is also highly (positively) correlated with the share of M2 in GDP. The finding that many of the "controls" in the regression, variables capturing 
Table 3

Correlations

\begin{tabular}{|c|c|c|c|c|c|c|c|c|}
\hline \multirow[b]{2}{*}{ reserves } & \multicolumn{3}{|c|}{ reserves fin_dev1 fin_dev2 } & \multirow[t]{2}{*}{ gdp } & \multicolumn{4}{|c|}{ kaopen M2/gdp public_liab private_liab } \\
\hline & 1 & & & & & & & \\
\hline fin_dev1 & .2028 & 1 & & & & & & \\
\hline fin_dev2 & .4076 & .5904 & 1 & & & & & \\
\hline $\operatorname{gdp}$ & .6823 & -.0721 & .2811 & 1 & & & & \\
\hline kaopen & -.3637 & -.4171 & -.3684 & -.3724 & 1 & & & \\
\hline $\mathrm{M} 2 / \mathrm{gdp}$ & .5823 & .4529 & .7495 & .3406 & -.4141 & 1 & & \\
\hline public_liab & .5851 & .3084 & .4083 & .7648 & -.4105 & .3224 & 1 & \\
\hline private_liab & .7518 & .4355 & .5641 & .7791 & -.5929 & .5993 & .8176 & 1 \\
\hline
\end{tabular}

Note: See app. C for explanations of the variables and data sources. fin_dev1 is a measure of financial market development based on each country's foreign equity and bond liabilities (graphed in fig. 5). fin_dev2 is a measure of financial market development based on each country's domestic equity and bond liabilities (graphed in fig. 6); this measure is not available for China and is also unavailable for a number of countries prior to 1988 (see app. $\mathrm{C}$ for details).

the precautionary and mercantilist motives, are correlated with the measures of financial development biases against the finding of an additional financial markets motive. In order to take account of possible multicollinearity (and interaction effects) among the explanatory variables, the various specifications in table 2 were rerun dropping individual variables one at a time. The results presented in table 2 were found to be robust to these exclusions.

A second issue that arises in these sorts of tests is endogeneity bias. Our tests examine whether various motivations (precautionary, mercantilist, and financial underdevelopment) lead countries to accumulate foreign reserves. Causality may, however, go the other way. It may be that countries with high levels of foreign reserves are more likely, for example, to maintain a fixed exchange rate, be the subject of a currency crisis, or be less concerned about developing domestic financial markets. Or, it may be that whatever drives countries to accumulate reserves also leads them to certain exchange rate, capital control, and financial market regimes. One possible candidate for this underlying motivation is national legal origin. La Porta, Lopez-de-Silanes, and Shleifer (1998) show that legal origin (English, French, German, or Scandinavian) helps to explain cross-country differences in financial development, providing a plausible instrumental variable for our analysis. The estimation results using dummies for the national legal origin as instruments yielded results qualitatively similar to those presented in table 2 , suggesting that endogeneity, at least between reserves and the financial development variables, is not a concern. ${ }^{17}$ 


\section{Table 4}

Panel Regressions Explaining Reserve Holdings Based on Precautionary, Mercantilist, and Financial Market Underdevelopment Motivations (Year Fixed Effects)

\begin{tabular}{lcc}
\hline & Includes & Includes \\
& fin_dev1 & fin_dev2 \\
\hline Constant & $1.28^{* * *}$ & $.81^{* * *}$ \\
GDP & $(.27)$ & $(.31)$ \\
& $.32^{* * *}$ & $.45^{* * *}$ \\
Exchange rate regime & $.03)$ & $(.04)$ \\
& -.024 & $-.14^{* *}$ \\
Capital controls (kaopen) & $(.04)$ & $(.05)$ \\
& $.04^{* * *}$ & $.05^{* * *}$ \\
Crisis dummy & $(.01)$ & $(.01)$ \\
& .06 & -.05 \\
Currency overvaluation & $(.11)$ & $(.11)$ \\
& $-.003^{*}$ & -.001 \\
Share of imports & $(.002)$ & $(.002)$ \\
& $.94^{* * *}$ & $1.01^{* * *}$ \\
Share of M2 & $(.13)$ & $(.13)$ \\
& $.16^{* *}$ & $.54^{* * *}$ \\
Public liabilities & $(.07)$ & $(.09)$ \\
& $-.04^{* *}$ & -.04 \\
Private liabilities & $(.02)$ & $(.03)$ \\
Financial market development & $.46^{* * *}$ & $.33^{* * *}$ \\
& $(.03)$ & $(.04)$ \\
Year fixed effects & $-.45^{* * *}$ & $-.29^{* * *}$ \\
Country fixed effects & $(.05)$ & $(.04)$ \\
$R^{2}$ within & Yes & Yes \\
$R^{2}$ between & No & No \\
Time observations & .75 & .74 \\
Number of countries & .87 & .92 \\
\hline Note: & 1,017 & 712 \\
& 50 & 49 \\
\hline
\end{tabular}

Note: Robust standard errors clustered by country are in parentheses. See app. C for explanations of the variables and data sources. fin_dev1 is a measure of financial market development based on each country's foreign equity and bond liabilities (graphed in fig. 5). fin_dev2 is a measure of financial market development based on each country's domestic equity and bond liabilities (graphed in fig. 6); this measure is not available for China and is also unavailable for a number of countries prior to 1988 (see app. C for details).

"Significant at the $90 \%$ confidence level.

** Significant at the $95 \%$ confidence level.

*** Significant at the $99 \%$ confidence level.

Tables 4 and 5 provide two additional sets of robustness tests. Table 4 presents results for the final specifications in table 2 , including year fixed effects (and omitting country fixed effects). The year effects are statistically significant, but again the coefficient estimates on the financial development measures do not change much from those reported in table 2. Interestingly, in these "between" regressions the capital controls 


\section{Table 5}

Panel Regressions Explaining Reserve Holdings Based on Precautionary, Mercantilist, and Financial Market Underdevelopment Motivations (Pooled Regression)

\begin{tabular}{|c|c|c|}
\hline & $\begin{array}{l}\text { Includes } \\
\text { fin_dev1 }\end{array}$ & $\begin{array}{l}\text { Includes } \\
\text { fin_dev2 }\end{array}$ \\
\hline Constant & $\begin{array}{c}-.72 \\
(.70)\end{array}$ & $\begin{array}{r}-1.24 \\
(.94)\end{array}$ \\
\hline GDP & $\begin{array}{l}.45^{* * *} \\
(.13)\end{array}$ & $\begin{array}{l}.69^{* * *} \\
(.16)\end{array}$ \\
\hline Exchange rate regime & $\begin{array}{l}-.11 \\
(.20)\end{array}$ & $\begin{array}{c}-.19 \\
(.14)\end{array}$ \\
\hline Capital controls (kaopen) & $\begin{array}{c}-.03 \\
(.05)\end{array}$ & $\begin{array}{c}-.01 \\
(.02)\end{array}$ \\
\hline Crisis dummy & $\begin{array}{c}-.27^{* * *} \\
(.13)\end{array}$ & $\begin{array}{l}-.38^{* * * *} \\
(.09)\end{array}$ \\
\hline Currency overvaluation & $\begin{array}{c}-.009^{* * *} \\
(.001)\end{array}$ & $\begin{array}{l}-.005^{* * *} \\
(.001)\end{array}$ \\
\hline Share of imports & $\begin{array}{l}1.63^{* * *} \\
(.11)\end{array}$ & $\begin{array}{l}1.56^{* * *} \\
(.22)\end{array}$ \\
\hline Share of M2 & $\begin{array}{l}.21^{*} \\
(.11)\end{array}$ & $\begin{array}{l}.31^{*} \\
(.16)\end{array}$ \\
\hline Public liabilities & $\begin{array}{l}.05 \\
(.07)\end{array}$ & $\begin{array}{c}-.16 \\
(.10)\end{array}$ \\
\hline Private liabilities & $\begin{array}{l}.36^{* * *} \\
(.11)\end{array}$ & $\begin{array}{l}.31^{*} \\
(.16)\end{array}$ \\
\hline Financial market development & $\begin{array}{l}-.46^{* * *} \\
(.13)\end{array}$ & $\begin{array}{c}-.08^{*} \\
(.05)\end{array}$ \\
\hline Time observations & 1,017 & 712 \\
\hline Number of country groups & 7 & 7 \\
\hline
\end{tabular}

Note: Generalized estimating equation population averaged model. Standard errors (adjusted for clustering on group) are in parentheses. See app. $C$ for explanations of the variables and data sources. Country groups are described in app. D. fin_dev1 is a measure of financial market development based on each country's foreign equity and bond liabilities (graphed in fig. 5). fin_dev2 is a measure of financial market development based on each country's domestic equity and bond liabilities (graphed in fig. 6); this measure is not available for China and is also unavailable for a number of countries prior to 1988 (see app. C for details).

"Significant at the $90 \%$ confidence level.

** Significant at the $95 \%$ confidence level.

${ }^{* * *}$ Significant at the $99 \%$ confidence level.

variable is positive and highly significant (suggesting that countries with more controls accumulate higher reserves). Unsurprisingly, the year fixed effects sweep out the crisis dummy. Finally, table 5 pools the various countries into seven regionally based groups. These robustness checks confirm the basic results presented in table 2: reserve-accumulating countries have higher private liabilities and less developed financial markets. 


\section{Conclusions}

Economists have long studied the question of optimal reserve holdings by governments. In the days when most countries were part of a fixed exchange rate system, reserves allowed countries to avoid costly adjustments to disturbances to external sectors of their economies. More recently, even as many countries allow their exchange rates more flexibility, reserves continue to be held for both precautionary and (possibly) mercantilist motives. This paper provides another rationale for reserve accumulation based on the distortions that arise in countries with underdeveloped financial markets.

Data from the financial accounts of industrial and developing countries indicate that reserve accumulations by developing countries have increased markedly in the past decade. Further, developing countries with high levels of investment receive lower, rather than higher, net capital inflows. The component of the financial account that is driving this counterintuitive relationship is official foreign reserves. This is puzzling, in that standard economic models suggest that capital should flow from rich to poor countries.

The negative relationship between rates of investment and capital inflows among developing countries is likely to reflect credit constraints. While financial markets in industrial countries have deepened and broadened, financial markets in many developing countries have not kept pace. In this context, incentives for firms in countries with less developed financial markets may be distorted, leading to underinsurance against future credit constraints. Sterilized reserve accumulation by governments results in a subsidy to the private sector, inducing it to save (through purchases of government bonds) as a way of insuring against future financing constraints.

The simple model presented in this paper provides two important empirical predictions for reserve-accumulating countries. They are, first, that the private sectors of these countries will underinsure against capital shortfalls and, second, that their financial markets will be relatively underdeveloped. Proxies for both these characteristics explain reserve holdings for 56 industrialized and developing countries over the period 1977-2004. Hence, it appears that the accumulation of foreign reserves by governments of developing countries may represent sensible responses to prevailing economic conditions. 


\section{Appendix A}

Table A1

Developing Countries Included in the Panel Estimates

\begin{tabular}{lclr}
\hline Country & IFS Code & \multicolumn{1}{c}{ Country } & IFS Code \\
\hline Argentina & 213 & Mexico & 273 \\
Brazil & 223 & Pakistan & 564 \\
Chile & 228 & Peru & 293 \\
China & 924 & Philippines & 566 \\
Colombia & 233 & Poland & 964 \\
Czech Republic & 935 & Russia & 922 \\
Egypt & 469 & Saudi Arabia & 456 \\
Estonia & 939 & Singapore & 576 \\
Hong Kong & 532 & Slovak Republic & 936 \\
Hungary & 944 & Slovenia & 961 \\
India & 534 & South Africa & 199 \\
Indonesia & 536 & South Korea & 542 \\
Israel & 436 & Taiwan & 528 \\
Latvia & 941 & Thailand & 578 \\
Lithuania & 946 & Turkey & 186 \\
Malaysia & 548 & Venezuela & 299 \\
\hline
\end{tabular}

\section{Appendix B}

\section{Table B1}

Industrial Countries Included in the Panel Estimates

\begin{tabular}{lclr}
\hline Country & IFS Code & \multicolumn{1}{c}{ Country } & IFS Code \\
\hline Australia & 193 & Italy & 136 \\
Austria & 122 & Japan & 158 \\
Belgium & 124 & Luxembourg & 137 \\
Canada & 156 & Netherlands & 138 \\
Denmark & 128 & New Zealand & 196 \\
Euro Area & 163 & Norway & 142 \\
Finland & 172 & Portugal & 182 \\
France & 132 & Spain & 184 \\
Germany & 134 & Sweden & 144 \\
Greece & 174 & Switzerland & 146 \\
Iceland & 176 & United Kingdom & 112 \\
Ireland & 178 & United States & 111 \\
\hline
\end{tabular}




\section{Appendix C}

\section{Panel Estimation Variable Definitions ${ }^{18}$}

Capital controls (CC): The Chinn and Ito (2006) capital controls index (kaopen), inverted so a higher number indicates more binding controls. Mean zero, $\min =-2.6025, \max =1.767$. Excludes Luxembourg; Netherlands, 1977-80; Switzerland, 1977-95; Taiwan; Russia, 1977-97; China, 1979-83; Czech Republic, 1977-97; Slovak Republic, 1977-97; Estonia, 1977-97; Latvia, 1977-97; Hungary, 1977-97; Lithuania, 1977-97; Slovenia, 1977-97; Poland, 1977-97.

Crisis dummy (Crisis): Based on the Frankel and Rose (1996) definition of a "crisis": a nominal depreciation of the currency of at least $25 \%$ relative to the previous year that is also at least a $10 \%$ acceleration, year over year, in the rate of depreciation.

Currency overvaluation (CurOver): Measure of currency overvaluation based on the PPP spot exchange rate. Excludes Taiwan; Korea; Russia, 1977-92; Czech Republic, 1977-92; Slovak Republic, 1977-92; Estonia, 1977-92; Latvia, 1977-91; Lithuania, 1977-91; Slovenia, 1977-90; Poland, 1977-89.

Exchange rate regime (ExRate): Based on the Reinhart and Rogoff (2004) de facto exchange rate regime classifications until 2001, updated by the author. Excludes Russia, 1977-91; Czech Republic, 1977-89; Slovak Republic, 1977-92; Estonia, 1977-90; Latvia, 1977-90; Lithuania, 1977-90; Slovenia, 1977-90; Poland, 1977-87.

Financial market development index (fin_dev1): External portfolio equity liabilities + total debt liabilities over GDP from Lane and MilesiFerretti (2007). Excludes Luxembourg, 1977-99; Greece, 1977-85; Peru, 1977-89; Hong Kong, 1977-78; Russia, 1977-92; China, 1977-80; Czech Republic, 1977-92; Slovak Republic, 1977-92; Estonia, 1977-92; Latvia, 1977-91; Hungary, 1977-83; Lithuania, 1977-92; Slovenia, 1977-91.

(Alternative) financial market development index ( fin_dev2): Private credit creation + stock market capitalization over GDP, as defined in Chinn and Ito (2009); data from the World Bank's database on financial development and structure (original source: Beck et al. 2000). Excludes United States, 1977-88; United Kingdom, 1977-88; Austria, 1977-88, 1998-99; Belgium, 1977-88, 1998-99; Denmark, 1977-88; France, 1977-88, 1998-99; Germany, 1977-88, 1990-91; Italy, 1977-88; Luxembourg, 1977-88, 1993-94, 1998-99; Netherlands, 1977-88; Norway, 1977-88; Sweden, 1977-88; Switzerland, 1977-88; Iceland, 1977-94; Ireland, 1977-95; Portugal, 1977; Spain, 1977-88; Turkey, 1977-80, 1985-86; 
Australia, 1977-88; New Zealand, 1977-88; South Africa, 1977-88; Argentina, 1977-87; Brazil, 1977-91; Chile, 1977-78; Colombia, 1986-87, 1989-90; Mexico, 1977; Peru, 1977-89; Venezuela, 1977, 1984-85; Israel, 1977-88; Saudi Arabia, 1977-91; Egypt, 1977-88; Taiwan; Hong Kong, 1977-90; India, 1978-79; Indonesia, 1977-80; Malaysia, 1977; Singapore, 1977-80; Russia, 1977-93; China; Czech Republic, 1977-94; Slovak Republic, 1977-94; Estonia, 1977-97; Latvia, 1977-95; Hungary, 1977-91; Lithuania, 1977-95; Slovenia, 1977-94; Poland, 1977-91.

(Adjusted alternative) financial market development index (fin_dev3): Private credit creation adjusted by a proxy for the involvement of the government in the creation of private credit + stock market capitalization over GDP, as defined in Chinn and Ito (2009); data from the World Bank's database on financial development and structure (original source: Beck et al. 2000). Excludes same observations as listed for fin_dev2.

GDP: Nominal GDP in millions of U.S. dollars from Lane and MilesiFerretti (2007). Excludes Czech Republic, 1977-91; Estonia, 1977-92; Latvia, 1977-91.

Imports (ShImp): Share of imports in GDP, World Development Indicators (WDI). Excludes Taiwan; Korea; Singapore, 2000-2004; Russia, 1977-88; Czech Republic, 1977-89; Slovak Republic, 1977-86; Estonia, 1977-91; Latvia, 1977-89; Lithuania, 1977-89; Slovenia, 1977-89; Poland, 1977-89.

M2/gdp: Ratio of M2 money supply to GDP; main source: WDI; missing data filled in using the International Financial Statistics (IFS) database. Excludes United Kingdom; Austria, 1977-79, 1998-2004; Belgium, 1977-79, 1998-2004; France, 1977-79, 1998-2004; Germany, 1977-79, 1999-2004; Italy, 1977-79, 1999-2004; Luxembourg; Netherlands, 1977-79, 1998-2004; Greece, 1977-79, 2001-4; Ireland, 1977-81, 1999-2004; Portugal, 1977-79, 1999-2004; Spain; Colombia, 1986-87, 1989-90; Taiwan; Hong Kong, 1977-91; Russia, 1977-93; China, 1977; Czech Republic, 1977-93; Slovak Republic, 1977-93; Estonia, 1977-91; Latvia, 1977-93; Hungary, 1977-82; Lithuania, 1977-93; Slovenia, 1977-91; Poland, 1977-84.

Private liabilities: Total foreign liabilities of private (bank and nonbank) borrowers from Bank for International Settlements (BIS) Consolidated Banking Statistics. Excludes United States, 1977-98; United Kingdom, 1977-98; Austria, 1977-98; Belgium, 1977-98; Denmark, 1977-98; France, 1977-98; Germany, 1977-98; Italy, 1977-98; Luxembourg, 1977-98; Netherlands, 1977-98; Norway, 1977-98; Sweden, 1977-98; Switzerland, 1977-98; Canada, 1977-98; Japan, 1977-98; Finland, 1977-98; Greece, 1977-82; Iceland, 1977-98; Ireland, 1977-98; Portugal, 1977-82; Spain, 1977-98; 
Turkey, 1977-82; Australia, 1977-82; New Zealand, 1977-82; South Africa, 1977-82; Argentina, 1977-82; Brazil, 1977-82; Chile, 1977-82; Colombia, 1977-82; Mexico, 1977-82; Peru, 1977-82; Venezuela, 1977-82; Israel, 1977-82; Saudia Arabia, 1977-82; Egypt, 1977-82; Taiwan, 1977-82; Hong Kong, 1977-82; India, 1977-82; Indonesia, 1977-82; Korea, 1977-82; Malaysia, 1977-82; Pakistan, 1977-84; Philippines, 1977-82; Singapore, 1977-82; Thailand, 1977-82; Russia, 1977-92; China, 1977-82; Czech Republic, 1977-92; Slovak Republic, 1977-92; Estonia, 1977-95; Latvia, 1977-94; Hungary, 1977-82; Lithuania, 1977-92, 1994-95; Slovenia, 1977-92; Poland, 1977-82.

Public liabilities: Total foreign liabilities of public borrowers from BIS Consolidated Banking Statistics. Excludes United States, 1977-98; United Kingdom, 1977-98; Austria, 1977-98; Belgium, 1977-98; Denmark, 1977-98; France, 1977-98; Germany, 1977-98; Italy, 1977-98; Luxembourg, 1977-98; Netherlands, 1977-98; Norway, 1977-98; Sweden, 1977-98; Switzerland, 1977-98; Canada, 1977-98; Japan, 1977-98; Finland, 1977-98; Greece, 1977-82; Iceland, 1977-98; Ireland, 1977-98; Portugal, 1977-82; Spain, 1977-98; Turkey, 1977-82; Australia, 1977-82; New Zealand, 1977-82; South Africa, 1977-82; Argentina, 1977-82; Brazil, 1977-82; Chile, 1977-82; Colombia, 1977-82; Mexico, 1977-82; Peru, 1977-82; Venezuela, 1977-82; Israel, 1977-82; Saudia Arabia, 1977-82; Egypt, 1977-82; Taiwan, 1977-82; Hong Kong, 1977-82; India, 1977-82; Indonesia, 1977-82; Korea, 1977-82; Malaysia, 1977-82; Pakistan, 1977-84; Philippines, 1977-82; Singapore, 1977-82; Thailand, 1977-82; Russia, 1977-92; China, 1977-82; Czech Republic, 1977-92; Slovak Republic, 1977-92; Estonia, 1977-95; Latvia, 1977-94; Hungary, 1977-82; Lithuania, 1977-92, 1994-95; Slovenia, 1977-92; Poland, 1977-82.

Private/public liabilities_loc: Private and public (public-sector and nonbank private-sector) liabilities from the BIS Locational Bank Statistics data. Excludes Luxembourg, 1977-82; Taiwan; Russia, 1977-92; Czech Republic, 1977-92; Slovak Republic, 1977-92; Estonia, 1977-92; Latvia, 1977-92; Lithuania, 1977-92; Slovenia, 1977-92.

Reserves: Total foreign reserves from Lane and Milesi-Ferretti (2007). Excludes Luxembourg, 1977-83, 1998; Russia, 1977-92; Czech Republic, 1977-92; Slovak Republic, 1977-92; Estonia, 1977-91; Latvia, 1977-91; Hungary, 1977-81; Lithuania, 1977-91; Slovenia, 1977-90. 


\section{Appendix D}

\section{Country Groups Used in Pooled Regressions}

1. East Asia and Pacific:

- China

- Indonesia

- Korea

- Malaysia

- Philippines

- Thailand

- Japan

- Australia

- New Zealand

- Taiwan

- Hong Kong

- Singapore

2. Europe and Central Asia

- Latvia

- Lithuania

- Poland

- Russia

- United Kingdom

- Austria

- Belgium

- Denmark

- France

- Germany

- Italy

- Luxembourg

- Netherlands

- Norway

- Sweden

- Switzerland 
- Finland

- Greece

- Iceland

- Portugal

- Spain

- Czech Republic

- Slovak Republic

- Estonia

- Hungary

- Slovenia

3. Latin America and Caribbean:

- Argentina

- Brazil

- Chile

- Colombia

- Mexico

- Peru

- Venezuela

4. Middle East and North Africa:

- Egypt

- Turkey

- Israel

- Saudi Arabia

5. South Asia:

- India

- Pakistan

6. Sub-Saharan Africa:

- South Africa

7. North America:

- Canada

- United States 


\section{Endnotes}

I am grateful to Eleanor Wiske Dillon and Joshua Montes for outstanding research assistance and to the International Policy Center at the Ford School of Public Policy for financial support. I thank the ISOM Board (Rich Clarida, Jeff Frankel, Francesco Giavazzi, Lucrezia Riechlin, Chris Pissarides, and Ken West), my discussants (Philippe Martin and Carmen Reinhart), and conference participants Menzie Chinn, Hiro Ito, and Philip Lane for many useful comments and suggestions. All remaining errors are my own.

1. In June 2009, Chinese foreign exchange reserves reached $\$ 2,132$ billion.

2. Caballero and Panageas (2004) suggest that while international reserve accumulation is not the best insurance against sudden stops, in practice many countries seem to rely on reserves for this purpose. See also Summers (2006) and Devereux (2009) for discussions of the reasons for and implications of reserve accumulation by developing countries.

3. This is often referred to as the "Greenspan-Guidotti rule."

4. Durdu, Mendoza, and Terrones (2009) show that emerging markets that face large external shocks have an incentive to hold reserves even when households and firms can smooth domestic income fluctuations. Alfaro and Kanczuk (2009) consider the joint decision to accumulate reserves and issue sovereign debt. In the context of a stochastic dynamic equilibrium model they find that optimal policy is not to hold reserves at all (since reserves can be used to pay down the debt). Of course, in practice countries generally both issue debt and hold reserves.

5. There is a large literature exploring the efficacy of sterilized intervention policy (see, e.g., Dominguez and Frankel 1993b; Fatum and Hutchison 2003). In the traditional portfolio balance model, sterilized intervention can be effective only if domestic and foreign assets are imperfect substitutes and Ricardian equivalence does not hold. Dominguez and Frankel (1993a) and Dominguez (2003) provide empirical evidence suggesting that sterilized interventions by industrial countries have, at times, effectively influenced currency values. The efficacy of sterilized intervention policies in developing countries has been less widely studied, in large part because governments have been reluctant to provide detailed data on their operations. Reinhart and Reinhart (2008) document the extent to which the accumulation of foreign exchange reserves has been sterilized by developing countries since 1990.

6. A notable exception is a recent study by Obstfeld, Shambaugh, and Taylor (2008), which suggests that if reserve adequacy is gauged against the size of the banking sector, the recent reserves accumulation in emerging markets is less puzzling.

7. Developing countries seem to be increasingly making direct investments into industrial countries, providing yet another example of the capital flow paradox (see Chari, Chen, and Dominguez 2009).

8. Loans are always worth it from the standpoint of the borrower because of the high return to reinvestment (the investment function is assumed to be strictly increasing, positive, and convex).

9. This measure of financial market development is not the "international financial integration" measure used in Lane and Milesi-Ferretti (2007), which is the sum of foreign assets (which includes reserve assets) and liabilities over GDP.

10. See, e.g., Aizenman and Marion (2003). Machlup (1966) argued that the behavior of governments toward reserve accumulation was very much like that of his wife with regard to her wardrobe: no matter how many dresses she possessed, she added to her stock of them each year. "Mrs. Machlup's wardrobe theory" involves including lagged values of reserves in the specification. Lagged reserves are generally not found to be statistically significant in any of the specifications estimated in this paper.

11. Previous studies have also included a number of different measures of the cost of holding reserves (generally an interest rate on foreign assets relative to a domestic benchmark). Rodrik (2006) estimates that the cost of holding reserves is close to 1\% of GDP for all developing countries; however, this variable is never found to be statistically or economically important in explaining reserve accumulations.

12. Data constraints limit the sample of countries included in the empirical work. In particular, none of the poorest countries are in the sample. One plausible implication from the simple model in Sec. III is that very poor countries that are completely closed to international 
flows have no incentive to hold foreign reserves. This implication is unfortunately not testable with the available data.

13. Martin and Rey (2006) intriguingly show that financial globalization in emerging markets may inherently lead to self-fulfilling financial crashes and further market incompleteness.

14. The predicted sign on public liabilities is less clear-cut than is the case for private liabilities. If governments fully sterilize reserve accumulations, this will result in higher public debt and a positive correlation with reserves. Excluding public liabilities in all relevant regression specifications has no qualitative effects on the other included variables; these results are not reported but are available on request.

15. In some developing countries, governments, rather than the private sector, play a large role in financial intermediation, e.g., by providing credit through state-owned institutions. In order to take this into account, one can use estimates from La Porta, Lopez-deSilanes, and Shliefer (2002) of the ratios of government ownership of banks to adjust the private credit creation component of fin_dev2. Estimates using this adjusted financial development measure ( fin_dev3) did not significantly differ from those reported using the unadjusted measure. These results are available on request.

16. One possible explanation for this is that the Obstfeld et al. paper is more focused on explaining cross-country (between) differences in reserve accumulation, whereas the inclusion of country fixed effects in this paper puts the focus on time-series (within-country) variation.

17. Another approach, taken by Cheung and Ito (2009) and Chinn and Ito (2009), is to use period averages rather than annual data to avoid time-dependent endogeneity. Ito and Chinn also instrument for financial development with the legal origin dummies in their panel regressions explaining current account balances, national saving, and investment.

18. Unless otherwise noted, data are available for all 56 countries from 1977 to 2004.

\section{References}

Aiyagari, S. R. 1994. "Uninsured Idiosyncratic Risk and Aggregate Saving." Quarterly Journal of Economics 109, no. 3:659-84.

Aizenman, J., and J. Lee. 2007. "International Reserves: Precautionary versus Mercantilist Views, Theory and Evidence." Open Economies Review 18:191-214.

Aizenman, J., and N. Marion. 2003. "The High Demand for International Reserves in the Far East: What Is Going On?" Journal of the Japanese and International Economies 17, no. 3:370-400.

Alfaro, L., and F. Kanczuk. 2009. "Optimal Reserve Management and Sovereign Debt." Journal of International Economics 77, no. 1:23-36.

Beck, T. H. L., A. Demirgüç-Kunt, and R. Levine. 2000. "A New Database on Financial Development and Structure." World Bank Economic Review 14, no. 3:597-605.

Ben-Bassat, A., and D. Gottlieb. 1992. "Optimal International Reserves and Sovereign Risk." Journal of International Economics 33:345-62.

Caballero, R., and A. Krishnamurthy. 2001. "International and Domestic Collateral Constraints in a Model of Emerging Market Crisis." Journal of Monetary Economics 48:513-48.

2004. "Smoothing Sudden Stops." Journal of Economic Theory 119:104-27.

2005. "Exchange Rate Volatility and the Credit Channel in Emerging Markets: A Vertical Perspective." International Journal of Central Banking 1:207-45.

Caballero, R., and S. Panageas. 2004. "Contingent Reserves Management: An Applied Framework." Working Paper no. 10786, NBER, Cambridge, MA.

Chari, A., W. Chen, and K. Dominguez. 2009. "Foreign Ownership and Firm Performance: Emerging-Market Acquisitions in the United States." Working Paper no. 14786, NBER, Cambridge, MA. 
Chen, W. 2007. "The Relationship between the Current Account and Its Components in Developing Countries." Manuscript (April), Economics Department, University of Michigan.

Cheung, Y., and H. Ito. 2009. "A Cross-Country Empirical Analysis of International Reserves." International Economic Journal 23, no. 4:447-81.

Chinn, M., and H. Ito. 2006. "What Matters for Financial Development? Capital Controls, Institutions, and Interactions." Journal of Development Economics 61, no. 1:163-92.

. 2009. "East Asia and Global Imbalances: Saving, Investment, and Financial Development." In Financial Sector Development in the Pacific Rim, ed. Takatoshi Ito and Andrew Rose. NBER-East Asian Seminar on Economics, vol. 18. Chicago: University of Chicago Press.

Devereux, M. 2009. "A Simple Model of Emerging Market Portfolio Structure." International Review of Economics and Finance 18:457-68.

Dominguez, K. M. 2003. "Foreign Exchange Intervention: Did It Work in the 1990s?" In Dollar Overvaluation and the World Economy, Special Report no. 15, ed. Fred Bergsten and John Williamson, 217-45. Washington, DC: Institute for International Economics.

Dominguez, K. M., and J. Frankel. 1993a. "Does Foreign Exchange Intervention Matter? The Portfolio Effect." American Economic Review 83:1356-69.

- 1993b. Does Foreign Exchange Intervention Work? Washington, DC: Institute for International Economics.

Dooley, M., D. Folkerts-Landau, and P. Garber. 2003. “An Essay on the Revived Bretton Woods System." Working Paper no. 9971, NBER, Cambridge, MA.

Durdu, C., E. Mendoza, and M. Terrones. 2009. "Precautionary Demand for Foreign Assets in Sudden Stop Economies: An Assessment of the New Mercantilism." Journal of Development Economics 89, no. 2:194-209.

Fatum, R., and M. Hutchison. 2003. "Is Sterilized Foreign Exchange Intervention Effective after All? An Event Study Approach." Economic Journal 113, no. 487:390-411.

Frankel, J., and A. Rose. 1996. "Currency Crashes in Emerging Markets: An Empirical Treatment." Journal of International Economics 41 (November): 351-66.

Frenkel, J., and B. Jovanovic. 1981. "Optimal International Reserves: A Stochastic Framework." Economic Journal 91 (June): 507-14.

Heller, H. R. 1966. “Optimal International Reserves." Economic Journal 76, no. 302:296-311.

Jeanne, O. 2007. "International Reserves in Emerging Market Countries: Too Much of a Good Thing?" Brookings Papers on Economic Activity, no. 1:1-55.

Jeanne, O., and R. Ranciere. 2009. "The Optimal Level of International Reserves for Emerging Market Countries: A New Formula and Some Applications." Working paper, Johns Hopkins University. http:/ / www.econ.jhu.edu/People/ Jeanne/JeanneRanciere_Feb09.pdf.

Lane, P., and D. Burke. 2001. "The Empirics of Foreign Reserves." Open Economies Review 12 (October): 423-34.

Lane, P., and G. Milesi-Ferretti. 2007. "The External Wealth of Nations Mark II." Journal of International Economics 73:223-50.

La Porta, R., F. Lopez-de-Silanes, and A. Shleifer. 1998. "Law and Finance." Journal of Political Economy 106, no. 6:1113-55.

—_ 2002. "Government Ownership of Banks." Journal of Finance 57, no. 1:265-301.

Lucas, R. 1990. "Why Doesn't Capital Flow from Rich to Poor Countries?" American Economic Review 80:92-96. 
Machlup, F. 1966. "The Need for Monetary Reserves." Banca Nazionale del Lavoro Quarterly Review 19:58-75.

Martin, P., and H. Rey. 2006. "Globalization and Emerging Markets: With or Without Crash?" American Economic Review 96, no. 5:1631-51.

Obstfeld, M., J. Shambaugh, and A. Taylor. 2008. "Financial Stability, the Trilemma, and International Reserves." Working Paper no. 14217, NBER, Cambridge, MA.

Reinhart, C., and V. Reinhart. 2008. "Capital Inflows and Reserve Accumulation: The Recent Evidence." Working Paper no. 13842, NBER, Cambridge, MA.

Reinhart, C., and K. Rogoff. 2004. "The Modern History of Exchange Rate Arrangements: A Reinterpretation." Quarterly Journal of Economics 119, no. 1:1-48.

Rodrik, D. 2006. “The Social Cost of Foreign Exchange Reserves." Working Paper no. 11952, NBER, Cambridge, MA.

Summers, L. 2006. "Reflections on Global Account Imbalances and Emerging Market Reserve Accumulation." L. K. Jha Memorial Lecture, Reserve Bank of India, March 24. 